\title{
Growth differences in 0-group plaice Pleuronectes platessa as revealed by otolith microstructure analysis
}

\author{
Maria Karakirii ${ }^{1}$, Rüdiger Berghahn ${ }^{2}$, Hein von Westernhagen ${ }^{1}$ \\ ${ }^{1}$ Biologische Anstalt Helgoland, Notkestr. 31, D-2000 Hamburg 52, Federal Republic of Germany \\ ${ }^{2}$ Institut für Hydrobiologie und Fischereiwissenschaft der Universität Hamburg, Olbersweg 24, D-2000 Hamburg 50, Federal \\ Republic of Germany
}

\begin{abstract}
Otolith increment analysis of 0-group plaice Pleuronectes platessa L. from the North Frisian Wadden Sea (F. R. Germany) revealed significant differences in size-at-age between 1981 and 1982. Backdating showed settlement to have occurred at about the same date in both years. Since water temperature conditions during the subsequent months in 1981 and 1982 were also almost identical, it is concluded that food limitation occurring in different parts of the nursery may have led to growth differences. The same holds true for differential growth of subpopulations in different nursery areas in 1981. Growth acceleration was reflected in the mean width of daily increments, deposited during the bottom-living stage, in otoliths of plaice which encountered rich feeding areas during the season. Furthermore, slower growth rate was observed in 0-group plaice populations on the edge of the Wadden Sea. However, time of settlement, as showed by daily increment readings, proved to be the same as in populations in the main nursery ground. In this case, retarded growth outside the nursery can be attributed to water temperature, food limitation or the action of breakers.
\end{abstract}

\section{INTRODUCTION}

Since Pannella (1971) first described daily growth increments in fish otoliths, several studies have been conducted on this subject. Otolith microstructure analyses have been carried out on tropical, temperate and cold water species (Struhsaker \& Uchiyama 1976, Campana \& Neilson 1982, Radtke \& Dean 1982), and effects of environmental factors on daily increment formation in various fish species have been studied under laboratory conditions (Wilson \& Larkin 1982, Campana 1984, Gutierrez \& Morales-Nin 1986, Eckmann \& Rey 1987). Daily increment analysis of fish otoliths also provides important information about early life events in studies on population dynamics (Brothers \& McFarland 1981, Victor 1982).

Plaice Pleuronectes platessa L. is a flatfish of great commercial importance in the North Sea. The transition to the bottom-dwelling mode of life, and the arrival and growth of this species in the Wadden Sea (the main North Sea nursery ground), have been well-studied (Ehrenbaum 1911, Bückmann 1934, Kuipers 1973,
1977. Rauck 1974a, Berghahn 1984, van der Veer 1986).

Otolith macrostructure of plaice has been considered in ageing studies (Reibisch 1899, Rauck 1974b). Some observations on the microstructure of plaice otoliths were also reported by Blacker (1975) and Berghahn (1985). Recent experiments on daily increment deposition in otoliths of early-stage plaice showed that the number of increments is age-dependent, while the increment width is growth-dependent (Karakiri 1989, Karakiri \& von Westernhagen 1989). Analysis of daily increments might thus reveal growth events in the life of individual plaice.

In the present study, microstructure was analysed in otoliths of 0-group plaice from the North Frisian Wadden Sea, F. R. Germany. We examined: (1) differences in otolith increment growth between 0-group plaice sampled in summer 1981 and in summer 1982 and assessed whether these differences were correlated with differences in food supply recorded in the nursery between the 2 years (Berghahn 1987a); (2) otolith incremental growth differences in 0 -group plaice between samples 
from areas with different food supply within the same year (Berghahn 1987a); (3) age differences between large 0 -group plaice individuals sampled in the nursery ground and the small plaice which occurred over the outer sand bars on the edge of the Wadden Sea.

\section{MATERIAL AND METHODS}

Sampling. Samples were collected on the tidal flats in the North Frisian Wadden Sea using a $2 \mathrm{~m}$ beam trawl operated from a flat-bottomed boat during high tide and a push net during low tide in breaker-pools along the beach on the edge of the Wadden Sea (Stn AS). High tide samples were taken along a transect, S2 (Fig. 1), perpendicular to the shore between Hamburger Hallig and Nordstrand Island. Sampling was carried out in 1981 and 1982. For dates and feeding conditions see Table 1.

Immediately after the catch all fish were fixed either directly in $96 \%$ ethanol or in buffered formalin and transferred to $96 \%$ ethanol a few weeks later.

Otolith preparation. A total of 110 otoliths of 0 -group plaice were used for otolith microstructure analysis.
Sagittae were removed after dissecting the postopercular area. After extraction otoliths were cleaned from adherent tissue and stored in $75 \%$ ethanol until final preparation. Only 1 sagitta was examined because a preliminary examination showed both left and right sagittae to be identical with regard to the microstructure discussed.

SEM preparation. Otolith microstructure analysis was carried out employing Scanning Electron Microscopy (SEM) in all cases in which exact age determination was required.

Air-dried otoliths were mounted in Schellack with the convex side up. For precise and plane grinding up to the midplane, otoliths were ground on a rotating glass-plate using silicium carbide as an abrasive (Karakiri \& von Westernhagen 1988). Grinding was carried out gradually, examining each specimen under a stereomicroscope until the sagittal midplane was reached. The otoliths were then rinsed with water and polished using fine silicium carbide (grain size ca $1 \mu \mathrm{m})$. Afterwards, the otoliths were rinsed, air-dried and etched for 2 to $5 \mathrm{~min}$ with $0.1 \mathrm{M}$ EDTA (ethylenediaminetetraacetate) buffered at $\mathrm{pH}$ 7.4. Finally, each specimen was rinsed well with distilled water and

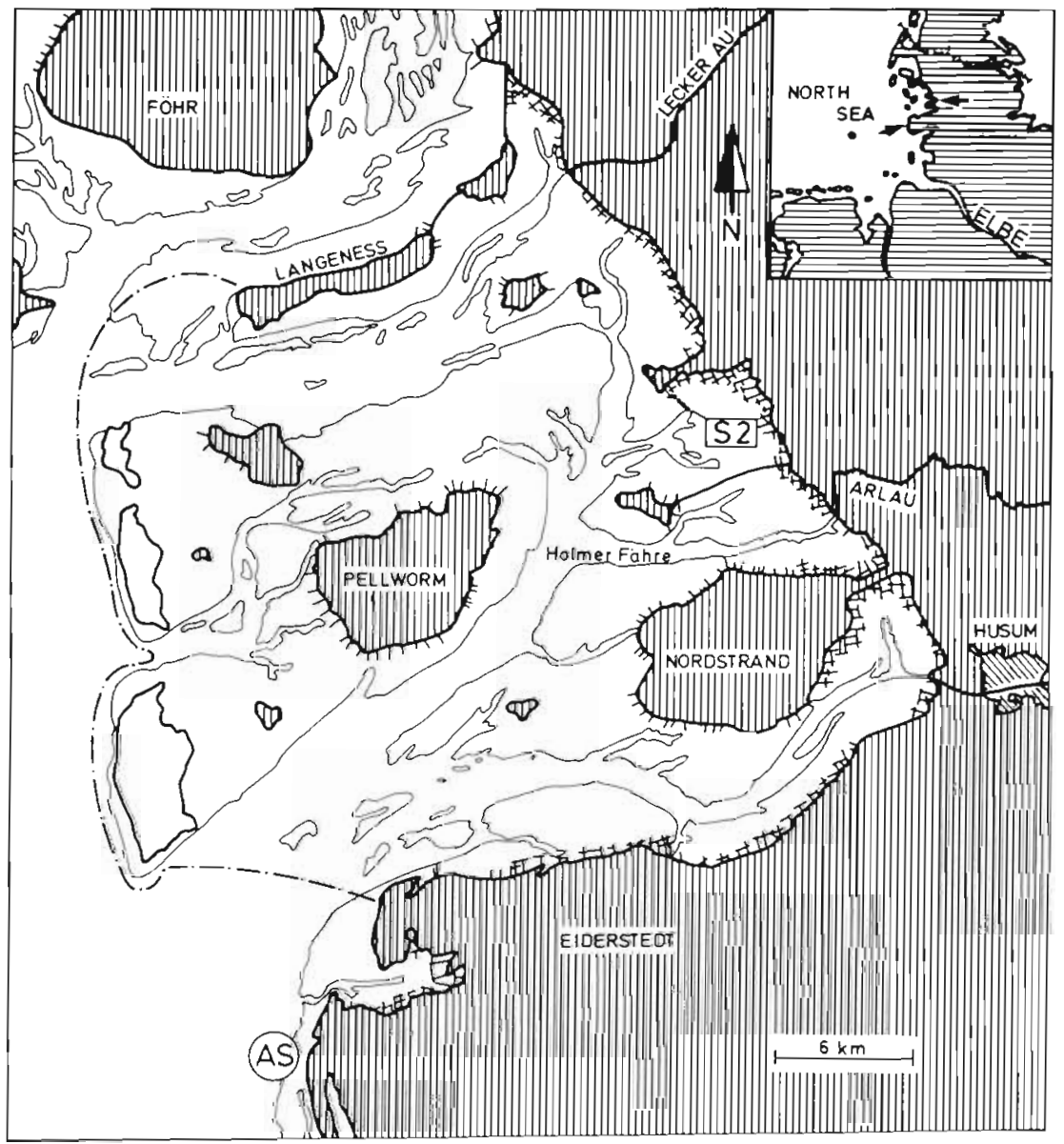

Fig. 1. Research area. S2: transect in the main nursery sampled during high tide; AS: station on the edge of the Wadden Sea sampled during low tide 
Table 1. Sampling dates and characterization of sampling areas according to feeding conditions as described by Berghahn (1987a). Samples from 16 June 1982 were taken at Stn AS. All other samples were taken in different sections along Transect S2

\begin{tabular}{|ccc|}
$\begin{array}{c}\text { Nursery ground } \\
\text { (limited food } \\
\text { supply) }\end{array}$ & $\begin{array}{c}\text { Nursery ground } \\
\text { (abundant food } \\
\text { supply) }\end{array}$ & $\begin{array}{c}\text { Poor feeding } \\
\text { area }\end{array}$ \\
\hline 25 May 1981 & 24 May 1982 & \\
6 Jul 1981 & 6 Jul 1982 & \\
& 5 Aug 1981 & 5 Aug 1981 \\
& 7 Aug 1981 & 7 Aug 1981 \\
& 12 Aug 1981 & 12 Aug 1981 \\
& 3 Sep 1981 1981 \\
& 18 Jun 1982 & 16 Jun 1982 \\
&
\end{tabular}

dried in an oven for 12 to $24 \mathrm{~h}$ according to size. Larger otoliths were additionally dried in a vacuum exsiccator in order to prevent artifacts and alterations caused by moisture.

Specimens were coated with gold and viewed with an SEM (Stereoscan 90, Cambridge Instr.). SEM photographs at various magnifications ( 70 to $2000 \times$ ) were used for counting daily increments and measuring increment widths.

Light microscopy preparation. Otoliths of 0-group plaice sampled in August and September 1981 were analysed by means of light microscopy; this was an appropriate method since it was only necessary to measure outer increment widths ranging from 4 to $10 \mu \mathrm{m}$.

Otolith preparation procedure was the same as described above. For light microscopy, however, otoliths needed to be ground and polished on both sides, but not etched. Afterwards, otoliths were cleaned of the mounting medium and embedded in Euparal. Otoliths were allowed to clear for $10 \mathrm{~d}$ in Euparal and examined under a compound light microscope connected to an image analysis system (Videoplan, Contron). Increment widths were measured along a predermined axis perpendicular to the increments $(400 \times$ magnification).

Prerequisites of otolith microstructure analysis. The following information from experimental data on plaice otolith microstructure (Karakiri \& von Westernhagen 1989) was taken into consideration:

- the first increment in plaice otoliths is deposited 4 to $6 \mathrm{~d}$ before hatching.

- following the first increment deposition, one increment is deposited each day and the process of daily increment deposition in otoliths of early-stage plaice is not interrupted by environmental changes.

- otolith growth in terms of increment widths reflects somatic growth and growth rate of young plaice.

\section{RESULTS}

The maximum diameter of the otoliths investigated ranged from 450 to $1500 \mu \mathrm{m}$. Plaice sagittae showed the clustered pattern typical for flatfish (Fig. 2a): the primordium formed during the late embryonic stages ranged from 18 to $23 \mu \mathrm{m}$ in diameter and was followed by a few thin increments $(<0.4 \mu \mathrm{m})$. In the later stages, increment width tends to increase as the larva grows (Fig. 2b). The transition to the bottom-dwelling mode of life is marked by the formation of 4 to 6 accessory primordia, which are new calcification centres. Increments deposited after the transition to the bottomliving stage are much wider than the larval ones, ranging from 4 to $8 \mu \mathrm{m}$ in fast-growing fish (Fig. 2c). Subdaily increments (usually 2 per daily increment) were deposited during the bottom-living stage.

\section{Growth and age in 1981 and 1982}

Among the 0-group plaice sampled in the nursery in the summers of 1981 (25 May and 6 July) and of 1982 (2 May and 6 July), individuals of the median length group were taken for otolith analysis. Size (total length; TL) of specimens sampled on 25 May 1981 ranged from 16 to $29.5 \mathrm{~mm}$ while that of specimens sampled on 24 May 1982 ranged from 30.5 to $36.5 \mathrm{~mm}$ indicating strong growth differences between the 2 years. Similarly, median length of plaice sampled on 6 July 1981 ranged from 18 to $46.5 \mathrm{~mm}$ whereas specimens sampled on the same date in the following year had reached 56.5 to $71 \mathrm{~mm}$. Otolith increment analysis of plaice from May 1981 and May 1982 revealed a range in age from 88 to $98 \mathrm{~d}$ (Fig. 3a); no age differences were detected between these 2 groups. The same was true for plaice sampled on 6 July 1981 and on 6 July 1982 (128 to $139 \mathrm{~d}$; Fig. 3b). Thus, these plaice of the same age showed extreme differences in size-at-age between the 2 years. However, no significant differences were found in the duration of the larval phase of all groups (55 to $70 \mathrm{~d}$ ). Consequently, daily increments deposited during the bottom-dwelling mode of life were wider in specimens sampled in 1982 (ranging from 2.8 to $4.2 \mu \mathrm{m}$ ) than those from specimens sampled in 1981 (ranging from 1.0 to $2.5 \mu \mathrm{m}$ ).

\section{Effects of different feeding conditions on otolith increments}

Feeding conditions in the area were assessed by Berghahn (1987a). Otolith increment width of plaice individuals sampled in August and early September of 1981 in areas with limited food supply (tidal flats close to 

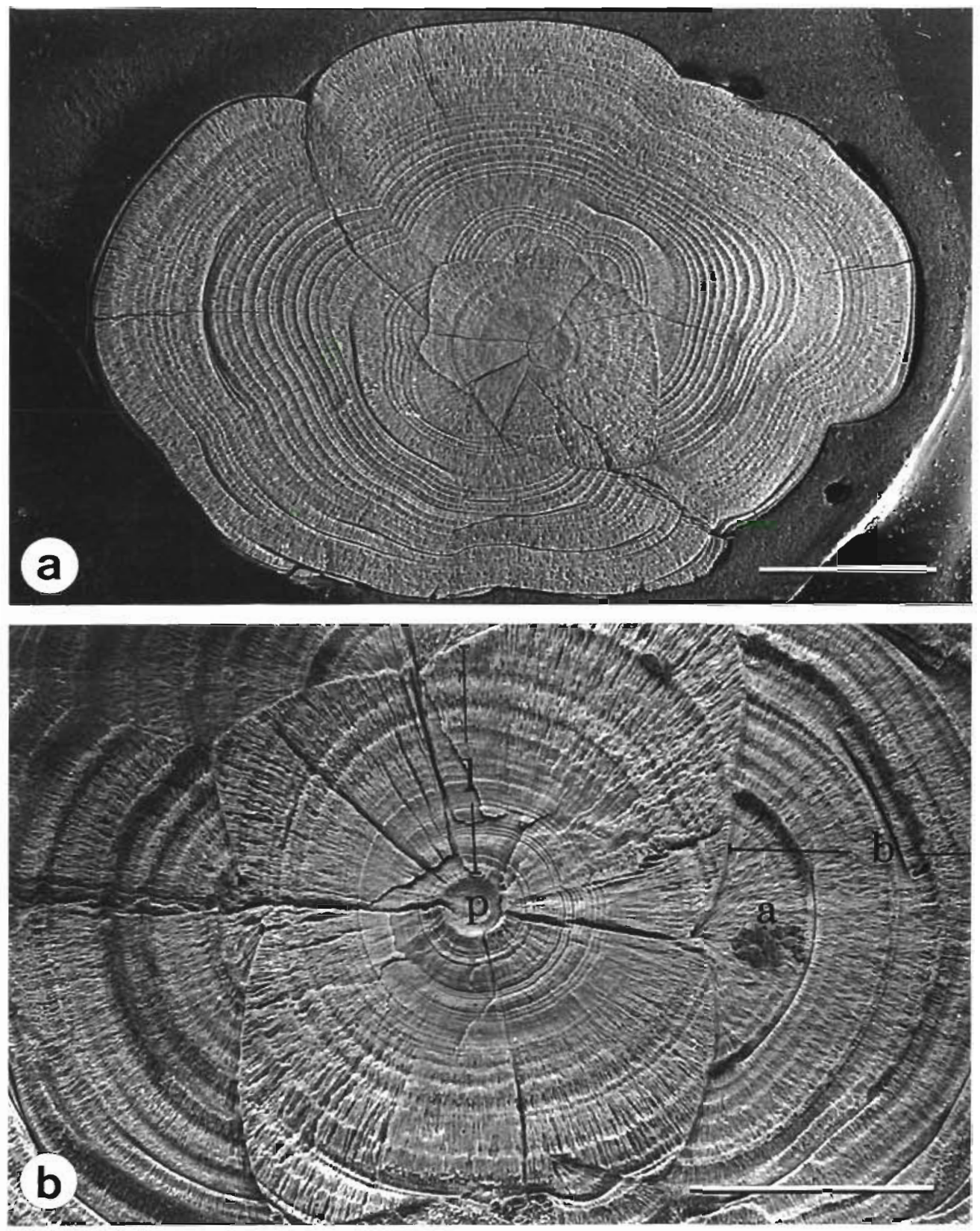

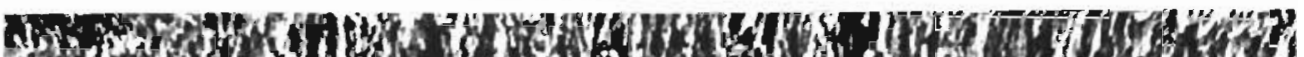

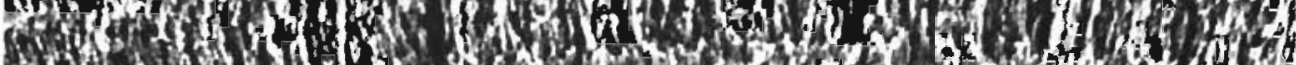

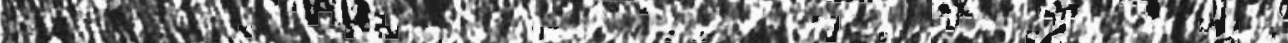

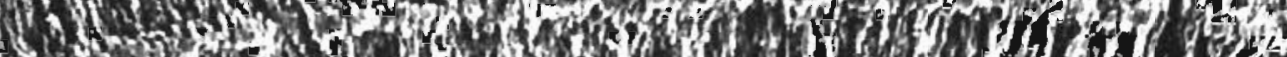
7 (A)

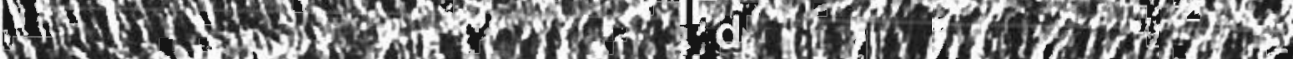

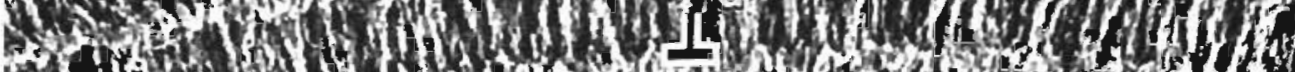
r. nits

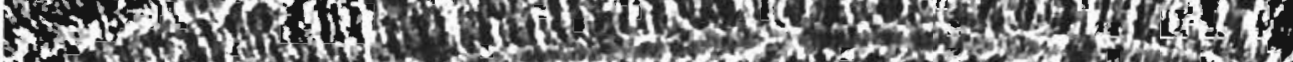
H. if 4.

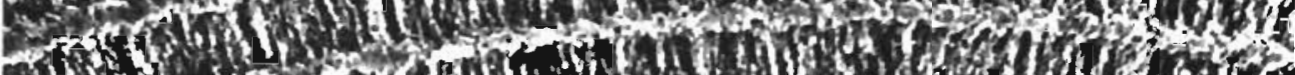
1.1.

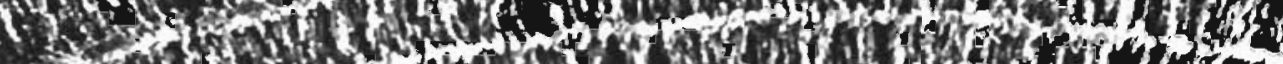

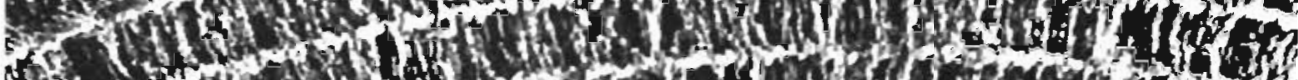

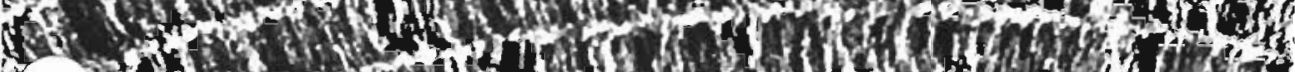

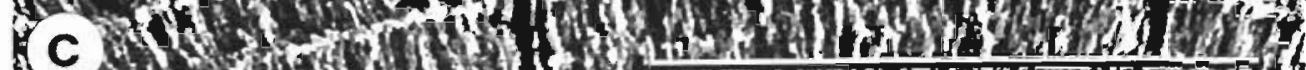
Sc a w

Fig. 2. Pleuronectes platessa. (a) Sagitta of a 22.5 min plaice caught on 25 May 1981. SEM; bar = $200 \mu \mathrm{m}$. (b) Typical clus tered pattern of a plaice sagitta; p: primordium, a accessory primordia, l larval-stage increments b: bottom-stage increments. Bar $=100 \mu \mathrm{m}$. (c) Daily increments deposited during the bottom-living stage; $d$ : one daily increment, arrow in dicates a subdaily incre-

ment. $\mathrm{Bar}=50 \mu \mathrm{m}$ 

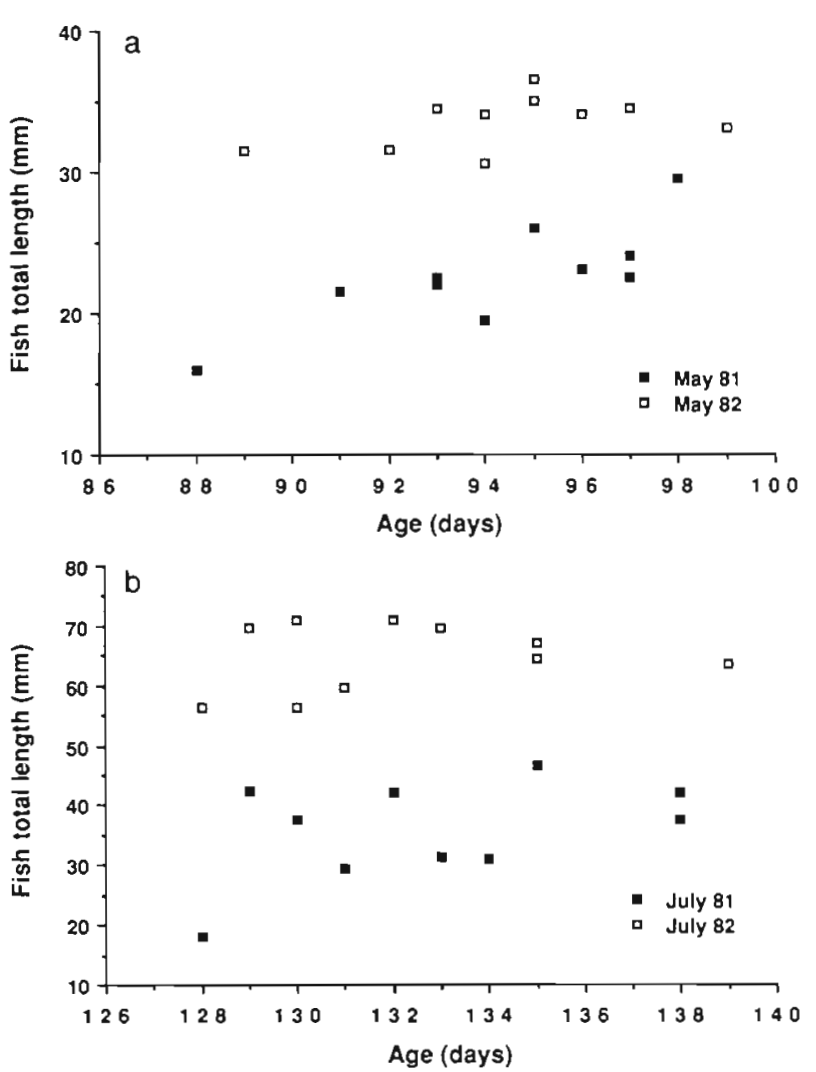

Fig. 3. Pleuronectes platessa. (a) Somatic growth differences of 0 -group plaice (median length group) between May 1981 and May 1982. Age determined from sagittae $(n=20)$. (b) Somatic growth differences of 0 -group plaice (median length group) between July 1981 and July 1982. Age determined from sagittae $(n=20)$

tidal channels) were significantly different (ANCOVA, $F=4.96, p<0.001)$ to those sampled in areas with an unlimited food supply (tidal flats). The significantly wider increments deposited during the last month in otoliths of the majority of plaice caught in early September in areas with abundant food supply ranged from 3.5 to $8 \mu \mathrm{m}$ (Fig. 4). On the other hand, plaice individuals sampled in August on the tidal flats close to tidal channels with limited food supply deposited relatively thin increments ranging from 4 to $5 \mu \mathrm{m}$.

\section{Otolith microstructure inside and outside the main nursery ground}

Otoliths were analysed from small plaice (16 to $20 \mathrm{~mm}$ ) caught in breaker pools on the edge of the Wadden Sea (Stn AS), outside the main nursery ground, and from large plaice (25 to $35 \mathrm{~mm}$ ) caught in the nursery field (Transect S2). Increment analysis revealed that the small individuals caught on 16 June 1982 outside the nursery were almost 4 mo old, the same age as the large individuals caught on 18 June 1982 in the nursery. The exceptionally slow growth of the specimens from the breaker pools was verified by the narrow increments deposited in the otoliths during the bottom-living stage, not exceeding 1.0 to $1.8 \mu \mathrm{m}$ (Fig. 5). In contrast, the width of increments of the bottom-stage large individuals caught inside the nursery ranged from 2.8 to $4 \mu \mathrm{m}$. No differences were found in the duration of the larval phase which ranged from 50 to $65 \mathrm{~d}$.

\section{DISCUSSION}

In this study, microstructure was analysed mainly with SEM on otoliths ground up to the midplane and etched. Reviews by Campana \& Neilson (1985) and Brothers (1987) recommended the development of a specific method of otolith preparation to obtain reliable results regarding number and widths of daily increments. Daily increment deposition in early-stage plaice otoliths was confirmed experimentally in previous work (Karakiri 1989, Karakiri \& von Westernhagen 1989). The same experimental studies revealed that increment deposition on plaice otoliths already starts in the prehatch stage, as reported for mummichog Fundulus heteroclitus (Radtke \& Dean 1982). Moreover, experimental studies showed mean increment width to reflect fish growth in both larval and juvenile plaice. Consequently, otolith increment analysis, apart from ageing, may provide an indicator of environmental conditions and changes and their influence on the growth rate of young plaice.

The analysed 0-group plaice otoliths revealed the pattern typical for flatfish otoliths described for other

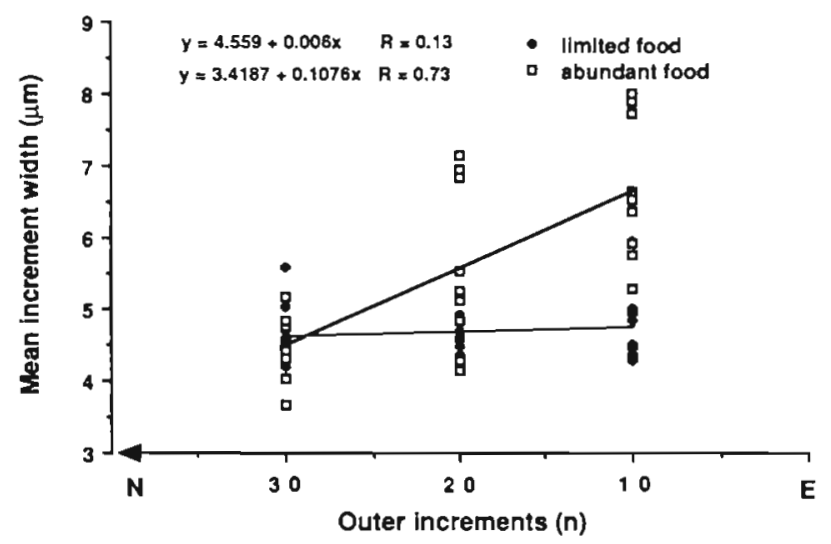

Fig. 4. Pleuronectes platessa. Differences in the mean width of the outer 30 increments in otoliths of 0-group plaice sampled in late summer 1981 in areas with limited food supply and in areas with abundant food supply. E: otolith edge; 10: outer increments; 20: subsequent 10 increments; 30: subsequent inner increments; $N$ : otolith nucleus. $n=50$ sagittae 
nehu, Stolephorus purpureus (Engraulidae), from the Hawaiian islands as indicated by daily growth increments of sagittae. Fish. Bull. U. S. 74: 9-17

Veer, H. W van der (1986). Immigration, settlement and density-dependent mortality of larval and early postlarval O-group plaice (Pleuronectes platessa L.) population in the western Wadden Sea. Mar. Ecol. Prog. Ser. 29: 223-236

Victor, B. C. (1982). Daily otolith increments and recruitment in two coral-reef wrasses Thalassoma bifasciatum and Halichoeres bivittatus. Mar. Biol. 71: 203-208

Volk, E. C., Wissmar, R. C., Simestad, C. A., Eggers, D. M

This article was submitted to the editor
(1984). Relationship between otolith microstructure and the growth of juvenile chum salmon (Onchorhynchus keta) under different prey rations. Can. J. Fish. Aquat. Sci. 41 : 126-133

Wilson, K. H., Larkin, P. A. (1982). Relationship between thickness of daily growth increments in sagittae and change in body weight of sockey salmon (Onchorhynchus nerka) fry. Can. J. Fish. Aquat. Sci. 39: 1335-1339

Zijlstra, J. J., Dapper, R., Witte, J. I. (1982) Settlement, growth and mortality of post-larval (Pleuronectes platessa) in the western Wadden Sea. Neth. J. Sea Res. 15: 250-272

Manuscript first received: June 24, 1988

Revised version accepted: April 19, 1989 